\title{
Incorporation of Vinyl Chloride in Insertion Polymerization**
}

\author{
Hannes Leicht, Inigo Göttker-Schnetmann, and Stefan Mecking*
}

\author{
Dedicated to Pierre Braunstein on the occasion of his 65th birthday
}

Catalytic polymerizations of ethylene and propylene are practiced industrially on a large scale. Vinyl chloride (VC) is the monomer produced on the largest scale after ethylene and propylene. ${ }^{[1]}$ However, the incorporation of VC into (co)polymers by insertion polymerization has remained elusive, and $\mathrm{VC}$ even inhibits polyethylene formation. ${ }^{[2]}$ The origin of this reactivity is believed to be very specific for VC. Unlike for other vinyl monomers, such as acrylates, ${ }^{[3-5]}$ acrylonitrile, ${ }^{[6]}$ and others, ${ }^{[7-12]}$ inhibition of polymerization by coordination of the functional groups of the free monomer and of repeat units formed from its incorporation into the polymer chain is not considered to be problematic for VC. Vinyl chloride is a weak $\kappa-\mathrm{Cl}$ donor (comparable, for example, to methylene chloride). Extensive studies with early- and late-transitionmetal catalysts have revealed that a different more fundamental problem prohibits the catalytic polymerization of vinyl chloride..$^{[2 \mathrm{a}-\mathrm{d}]}$ Thermodynamically favorable $\beta$-chloride elimination occurs subsequently to the incorporation of VC into the growing chain to afford inactive metal chloride complexes, and thus irreversibly deactivates the catalyst.

The B-chloro substituted alkyl species that undergo this detrimental reaction are formed by a net 1,2-insertion of VC into the growing chain. For an insertion of $\mathrm{VC}$ into latetransition-metal-carbon bonds, DFT calculations ${ }^{[2 \mathrm{a}, \mathrm{b}, \mathrm{d}]}$ and experimental evidence point to an initial insertion in a 2,1fashion. However, the propensity of late-transition-metal polymerization catalysts for "chain-walking" results in a net 1,2-incorporation of VC (Scheme 1). This unfavorable outcome has been observed for $\alpha$-diimine palladium complexes, bis(imino)pyridine iron and cobalt complexes, and for salicylaldiminato, and phosphine-enolato nickel complexes. ${ }^{[2, \mathrm{~d}, 13]}$

Owing to the low propensity of neutral phosphinesulfonato palladium complexes for chain walking, ${ }^{[14]}$ we decided to study their polymerization properties towards vinyl chloride. Most recently, related cationic phosphinephosphine oxide palladium catalysts have been reported to exhibit reduced activity for ethylene polymerization in the presence of VC. However, an ethylene homopolymer that has

[*] H. Leicht, Dr. I. Göttker-Schnetmann, Prof. Dr. S. Mecking Department of Chemistry, University of Konstanz Universitätstrasse 10, 78464 Konstanz (Germany) E-mail: stefan.mecking@uni-konstanz.de

[***] Financial support by Solvay SA, Belgium is gratefully acknowledged. We enjoyed stimulating discussions with Vincent Bodart and Thomas Hermant. Thomas Rünzi is gratefully acknowledged for XRay diffraction analyses of $\left[\mathrm{L} 2 \mathrm{PdCH}_{3} \mathrm{tmeda}_{0.5}\right]$ and $\left[\left\{\mathrm{L}^{2} \mathrm{PdCH}_{3}\right\}_{2}\right]$, and for providing complex [ $\left.\mathrm{L2PdCH}_{3}(\mathrm{dmso})\right]$.

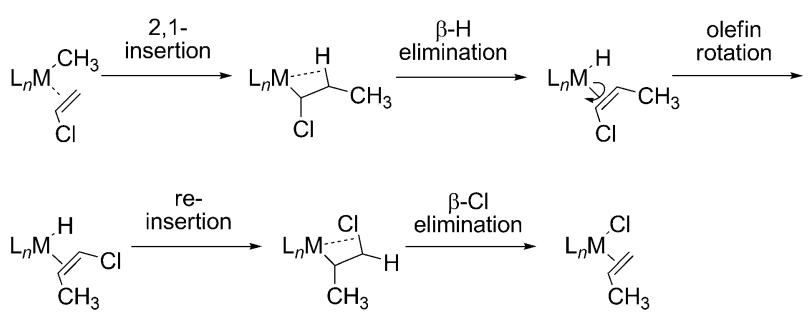

Scheme 1. 2,1-Insertion of VC into a metal methyl bond, net-1,2insertion by chain walking, and $\beta-\mathrm{Cl}$ elimination.

no detectable chlorine content is formed by these catalysts. ${ }^{[2 \mathrm{e}]}$ We now report, that among complexes L1Pd to L4Pd studied (Figure 1), complexes $\left[\mathbf{L} 2 \mathrm{PdCH}_{3}(\mathrm{dmso})\right], \quad\left[\left\{\mathbf{L} 2 \mathrm{PdCH}_{3}\right\}_{2}\right]$, $\left[\mathbf{L} 2 \mathrm{PdH}\left(\mathrm{P} t \mathrm{Bu}_{3}\right)\right]$, and $\left[\mathbf{L} 4 \mathrm{PdCH}_{3}(\mathrm{dmso})\right]$ catalyze the formation of chlorinated copolymers from ethylene and $\mathrm{VC}$ owing to a partial suppression of chain walking after monomer insertion.

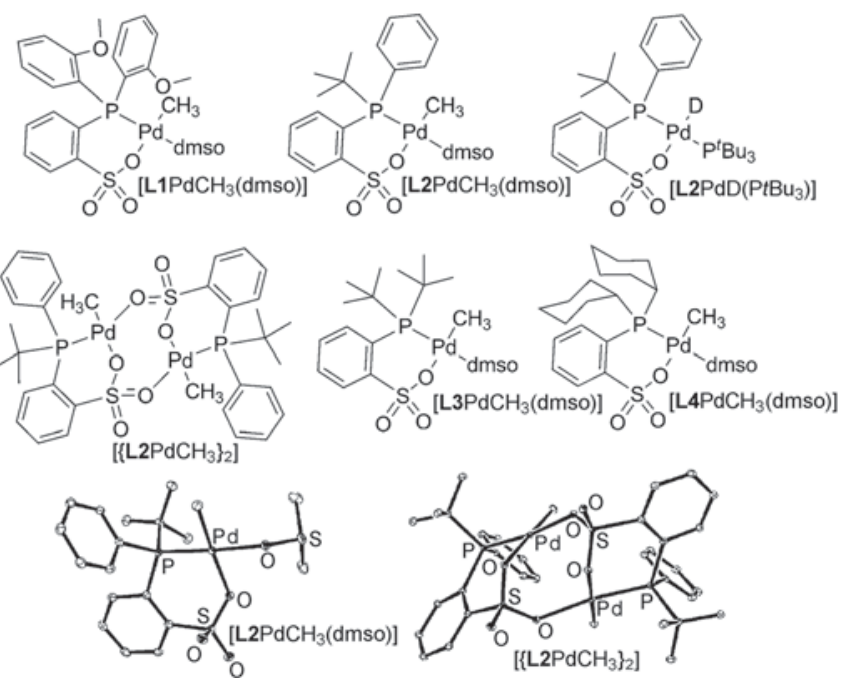

Figure 1. Catalyst precursors L1Pd to L4Pd and ORTEP plots of $\left[\mathrm{L} 2 \mathrm{PdCH}_{3}(\mathrm{dmso})\right]$ and $\left[\left\{\mathrm{L} 2 \mathrm{PdCH}_{3}\right\}_{2}\right]$ with hydrogen atoms omitted for clarity and thermal ellipsoids set at $50 \%$ probability. ${ }^{[15]}$

Prior to copolymerization experiments, the reactivity of $\left[\mathbf{L 1 P d C H}{ }_{3}(\mathrm{dmso})\right]$ toward $\mathrm{VC}$ was assessed by monitoring experiments by NMR spectroscopy (caution: VC is carcinogenic and requires special safety measures, see the Supporting Information). $\mathrm{VC}$ (4.3 equiv) insertion into $\left[\mathbf{L 1 P d C H}_{3}^{-}\right.$ (dmso)] occurs, albeit slowly, at $298 \mathrm{~K}$ in $\left[\mathrm{D}_{2}\right]$ methylene chloride solution. A chloroalkyl palladium complex is not detected, but formation of propylene (by $\beta-\mathrm{Cl}$ elimination) 


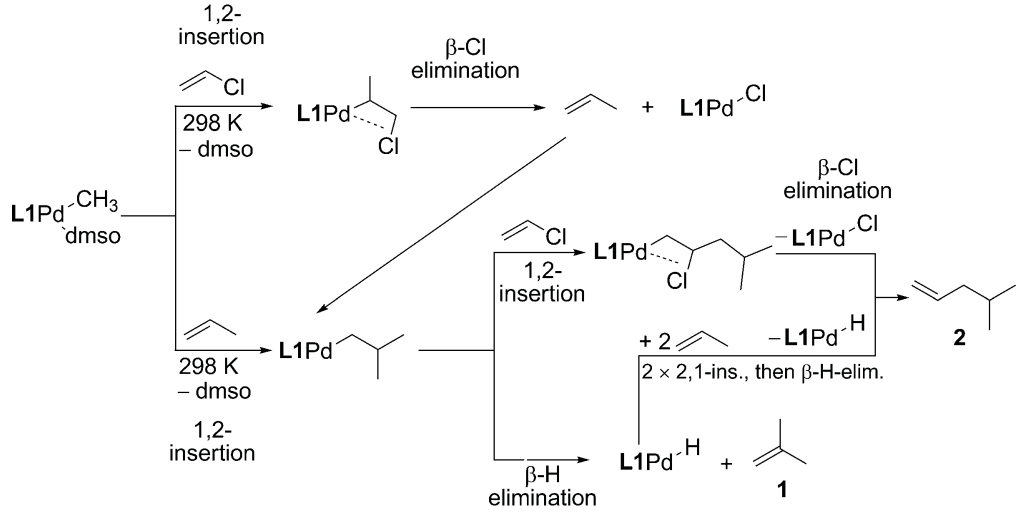

Scheme 2. Formation of propylene, iso-butene (1), and 4-methyl-pent-1-ene (2) by reaction of VC with [ $\left.\mathrm{LIPdCH}_{3}(\mathrm{dmso})\right]$. [ $\left.\mathrm{LIPdCH}_{2} \mathrm{CH}\left(\mathrm{CH}_{3}\right)_{2}\right]$, propylene, $\mathbf{1}$, and $\mathbf{2}$ were all identified by NMR spectroscopy.

after net 1,2-insertion of $\mathrm{VC}$ is evident after $5 \mathrm{~min}$. The propylene formed reacts faster than $\mathrm{VC}$ with the remaining $\left[\mathbf{L 1 P d C H}{ }_{3}(\mathrm{dmso})\right]$ to form a palladium isobutyl complex, $\left[\mathbf{L 1 P d C H}{ }_{2} \mathrm{CH}\left(\mathrm{CH}_{3}\right)_{2}\right]$, by 1,2-insertion (Scheme 2). $\left[\mathbf{L 1 P d C H} \mathrm{CH}_{2} \mathrm{CH}\left(\mathrm{CH}_{3}\right)_{2}\right]$ undergoes $\beta-\mathrm{H}$ elimination to afford iso-butene (1), as identified by comparison to genuine samples of $\mathbf{1}$. In addition, 4-methylpentene (2) forms either by $\mathrm{VC}$ insertion into $\left[\mathbf{L 1 P d C H} \mathrm{CH}_{2} \mathrm{CH}\left(\mathrm{CH}_{3}\right)_{2}\right]$ followed by $\beta-\mathrm{Cl}$ elimination, or by double insertion of propylene into a palladium hydride followed by $\beta$-hydride elimination. Furthermore, acetaldehyde slowly forms by (catalyzed) hydrolysis of $\mathrm{VC}$ owing to the presence of traces of water.

Given the known higher propensity for ethylene insertion into $\left[\mathbf{L A P d C H}_{3}(\mathrm{dmso})\right]$ than for propylene insertion, these results suggest that ethylene-VC copolymerizations need to be conducted at moderate (3-4 bar) ethylene pressure to facilitate significant VC insertion. Except for the control experiments in the absence of catalyst or ethylene, all experiments resulted in the formation of a polymer, which was analyzed by NMR spectroscopy and gel permeation chromatography (GPC; Table 1; for details see the Supporting Information). During these polymerizations the color of the reaction mixture changes from nearly colorless to the pale yellow color that is indicative of decomposed catalyst. Based on this observation the catalyst half-life time under polymerization conditions is estimated to approximately $20 \mathrm{~min}$ (see the Supporting Information). Generic catalyst decomposition pathways have been recently identified. ${ }^{[14 b]}$ However, we believe that net 1,2insertion of $\mathrm{VC}$ followed by $\beta$-chloride elimination as observed in the experiments monitored by NMR spectroscopy (see above) constitutes a major decomposition route.

NMR analyses of the polymers obtained indicate that $\mathrm{CHCl}$ units have not been incorporated in a midchain fashion in detectable amounts. ${ }^{[16]}$ However, signals typical of (long-chain) 2-chloroalkanes were present in the ${ }^{1} \mathrm{H}$ and ${ }^{13} \mathrm{C}$ NMR spectra, indicating up to $0.1 \%$ incorporation of VC when complexes $\left.\left[\mathbf{L} 2 \mathrm{PdCH}_{3}(\mathrm{dmso})\right],\left[\{\mathbf{L} 2 \mathrm{PdCH}\}_{3}\right\}_{2}\right]$, or $\left[\mathbf{L} 4 \mathrm{PdCH}_{3}(\mathrm{dmso})\right]$ were used (Figure 2 and Table 1$)$. Most characteristic, the $\mathrm{CH}_{3} \mathrm{CHClCH}_{2}-\mathrm{R}$ proton resonates at $4.08 \mathrm{ppm}$ as a virtual sextet with $J_{\mathrm{HH}}=6.3 \mathrm{~Hz}$, which is correlated to a ${ }^{13} \mathrm{C}$ signal at $58.44 \mathrm{ppm}$ through ${ }^{1} J_{\mathrm{CH}}$. This $\mathrm{CHCl}$ signal couples to a doublet $\left({ }^{3} J_{\mathrm{HH}}=6.6 \mathrm{~Hz}\right)$ at $1.56 \mathrm{ppm}$ $\left(\mathrm{CH}_{3} \mathrm{CHClCH}_{2}-\mathrm{R} ;{ }^{13} \mathrm{C} \mathrm{NMR:} 25.16 \mathrm{ppm}\right)$ and to a multiplet at $\delta=1.78 \mathrm{ppm}\left(\mathrm{CH}_{3} \mathrm{CHClCH}_{2}-\mathrm{R} ;{ }^{13} \mathrm{C} \mathrm{NMR}: 40.54 \mathrm{ppm}\right)$, as deduced from ${ }^{1} \mathrm{H}$ homodecoupling, 1D ${ }^{1} \mathrm{H}$ TOCSY-, ${ }^{1} \mathrm{H},{ }^{1} \mathrm{H}$ gCOSY, and ${ }^{1} \mathrm{H},{ }^{13} \mathrm{C}$ gHSQC experiments. Furthermore, these resonances match the respective resonances of 2chloroheptane, 2-chlorodecane, and 12-chlorotridecan-1-ol (for details see the Supporting Information). ${ }^{[17]}$

Table 1: Ethylene-VC copolymerizations with catalyst precursors L1Pd to L4Pd. ${ }^{[a]}$

\begin{tabular}{|c|c|c|c|c|c|c|c|c|c|c|c|c|}
\hline entry & $\begin{array}{l}\text { catalyst } \\
\text { precursor }\end{array}$ & $\begin{array}{l}T \\
{[\mathrm{~K}]}\end{array}$ & $\begin{array}{l}\text { cat. } \\
{[\mu \mathrm{mol}]}\end{array}$ & $\begin{array}{l}p\left(\mathrm{C}_{2} \mathrm{H}_{4}\right) \\
\text { [bar] }\end{array}$ & $\begin{array}{l}\text { VC } \\
{[\mathrm{g}]}\end{array}$ & $n_{\mathrm{vc}}: n_{\mathrm{cat}}$ & $\begin{array}{l}\text { yield } \\
{[\mathrm{mg}]}\end{array}$ & $\begin{array}{l}\mathrm{TON}^{[\mathrm{b}]} \\
\mathrm{C}_{2} \mathrm{H}_{4}\end{array}$ & $\begin{array}{l}\text { inc. VC } \\
{[\mathrm{mol} \%]^{[c]}}\end{array}$ & $\begin{array}{l}n[\mathrm{PE}] / n- \\
{[\mathrm{mCPE}]^{[\mathrm{d}]}}\end{array}$ & $\begin{array}{l}M_{\mathrm{n}}(\mathrm{NMR}) \\
{\left[\mathrm{g} \mathrm{mol}^{-1}\right]^{[\mathrm{f}]}}\end{array}$ & $\begin{array}{l}M_{\mathrm{n}}(\mathrm{GPC}) \\
{\left[\mathrm{g} \mathrm{mol}^{-1}\right]^{[\mathrm{g}]}\left(M_{\mathrm{w}} /\right.} \\
\left.M_{\mathrm{n}}\right)\end{array}$ \\
\hline 1 & {$\left[\mathrm{~L} \mathrm{PdCH} \mathrm{H}_{3}(\mathrm{dmso})\right]$} & 353 & 50 & 4 & 2.2 & 704 & 123 & 88 & - & n.a. ${ }^{[\mathrm{e}]}$ & 4700 & $2600(1.8)$ \\
\hline 2 & $\left.\left[\left\{\mathrm{~L}^{2} \mathrm{PdCH}\right\}_{3}\right\}_{2}\right]$ & 353 & 42 & 4 & 1.9 & 724 & 100 & 85 & 0.084 & $3.3: 1$ & 8000 & $4200(2.4)$ \\
\hline 3 & {$\left[\left\{\mathrm{~L}^{2} \mathrm{PdCH} \mathrm{H}_{3}\right\}_{2}\right]$} & 343 & 45 & 4 & 1.5 & 533 & 179 & 142 & 0.066 & $4.6: 1$ & 8000 & $4400(2.6)$ \\
\hline 4 & {$\left[\left\{\mathrm{~L}^{2} \mathrm{PdCH} \mathrm{H}_{3}\right\}_{2}\right]$} & 313 & 45 & 4 & 0.4 & 142 & 177 & 140 & 0.029 & $9.8: 1$ & 8400 & 4000 (1.6) \\
\hline 5 & $\left.\left[\left\{\mathrm{~L}^{2} \mathrm{PdCH}\right\}_{3}\right\}_{2}\right]$ & 313 & 45 & - & 0.5 & 178 & - & - & - & n.a. ${ }^{[e]}$ & - & - \\
\hline 6 & {$\left[\mathrm{~L} 2 \mathrm{PdCH}_{3}(\mathrm{dmso})\right]$} & 343 & 47 & 4 & 3.2 & 1089 & 127 & 96 & 0.106 & $5.0: 1$ & 4500 & $2600(2.2)$ \\
\hline 7 & {$\left[\mathrm{~L} 2 \mathrm{PdCH}_{3}(\mathrm{dmso})\right]$} & 323 & 47 & 4 & 1.2 & 409 & 268 & 203 & 0.049 & $2.4: 1$ & 14400 & $8000(1.5)$ \\
\hline 8 & {$\left[\mathrm{~L}^{2} \mathrm{PdCH}_{3}(\mathrm{dmso})\right]$} & 343 & 45 & 4 & 1.8 & 640 & 282 & 223 & 0.063 & $5.2: 1$ & 7100 & $5500(1.8)$ \\
\hline 9 & {$\left[\mathrm{~L} \mathrm{PdCH}_{3}\right.$ (dmso)] } & 303 & 45 & 4 & 2.8 & 996 & 315 & 250 & - & n.a. ${ }^{[e]}$ & 5900 & $6600(1.6)$ \\
\hline 10 & {$\left[\mathrm{~L} \mathrm{PdCH}{ }_{3}(\mathrm{dmso})\right]$} & 333 & 45 & 4 & 2.3 & 818 & 298 & 236 & 0.048 & $3.4: 1$ & 13400 & $6000(2.5)$ \\
\hline 11 & - & 343 & - & 4 & 3.6 & - & - & - & - & n.a. ${ }^{[e]}$ & - & - \\
\hline 12 & {$\left[\mathrm{~L}^{2} \mathrm{Pd}^{13} \mathrm{CH}_{3}(\mathrm{dmso})\right]$} & 343 & 47 & 4 & 2.6 & 885 & 215 & 163 & 0.082 & $3.2: 1$ & 8100 & $5300(1.8)$ \\
\hline 13 & {$\left[\mathrm{~L} \mathrm{Pd}^{13} \mathrm{CH}_{3}\right.$ (dmso) $]$} & 343 & 47 & 3 & 2.6 & 885 & 151 & 115 & 0.096 & $3.6: 1$ & 6100 & $3000(2.2)$ \\
\hline 14 & {$\left[\mathrm{~L} 2 \mathrm{PdH}\left(\mathrm{PtBu}_{3}\right)\right]$} & 358 & 19 & 3.2 & 1.7 & 1432 & 15 & 28 & 0.399 & $1.8: 1$ & 3900 & n.d. ${ }^{[\mathrm{h}]}$ \\
\hline
\end{tabular}

[a] For $2 \mathrm{~h}$ in $100 \mathrm{~mL}$ toluene, see the Supporting Information. [b] Turnover number (TON): polymerized $\mathrm{C}_{2} \mathrm{H}_{4}$ per Pd present (mol/mol). [c] Incorporated VC determined by integration of the $\mathrm{CH}_{3} \mathrm{CHClCH}_{2}-\mathrm{R}^{1} \mathrm{H} N M R$ signal versus polyethylene (PE) backbone signals in $\mathrm{C}_{2} \mathrm{D}_{2} \mathrm{Cl}_{4}$ at $373-$ $383 \mathrm{~K}$. [d] Ratio of PE chains/monochlorinated PE chains ( $\mathrm{mCPE}$ ) determined by ${ }^{1} \mathrm{H}$ NMR spectroscopy from the ratio of olefinic group versus $\mathrm{CH}_{3} \mathrm{CHCl}$ group signals. [e] Not applicable. [f] Determined by integration of the olefinic versus backbone ${ }^{1} \mathrm{H} \mathrm{NMR}$ signals. [g] Determined by high temperature GPC in trichlorobenzene at $403 \mathrm{~K}$ versus linear PE standards. [h] Not determined. 


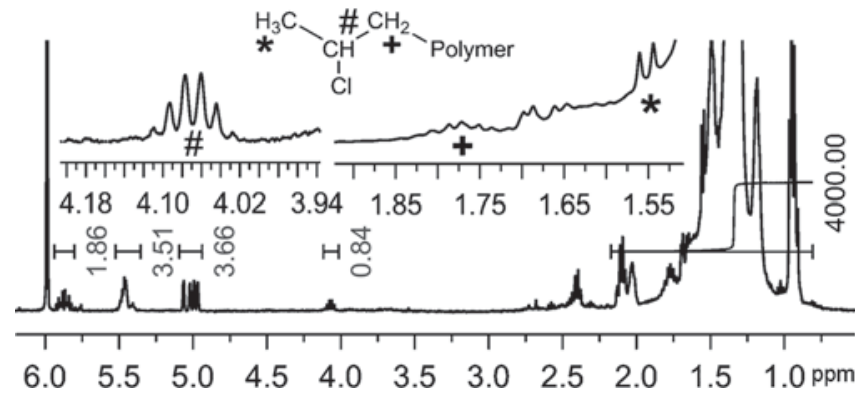

Figure 2. 'H NMR spectrum of ethylene-VC copolymer (entry 2, Table 1) with characteristic $\mathrm{CH}_{3} \mathrm{CHClCH}_{2}$ end group signals.

These $\mathrm{CH}_{3} \mathrm{CHClCH}_{2}-\mathrm{R}$ groups may be formed either by 1,2-insertion of $\mathrm{VC}$ into the palladium methyl bond of $\left[\mathbf{L} 2 \mathrm{PdCH}_{3}(\mathrm{dmso})\right],\left[\left[\mathbf{L} 2 \mathrm{PdCH}_{3}\right\}_{2}\right]$, or $\left[\mathbf{L} 4 \mathrm{PdCH}_{3}(\mathrm{dmso})\right]$ and subsequent ethylene insertion (also cf. Scheme 3 a), or by 2,1 insertion into a palladium hydride complex and subsequent ethylene insertion (also cf. Scheme $3 b$ ). ${ }^{[18]}$ To determine

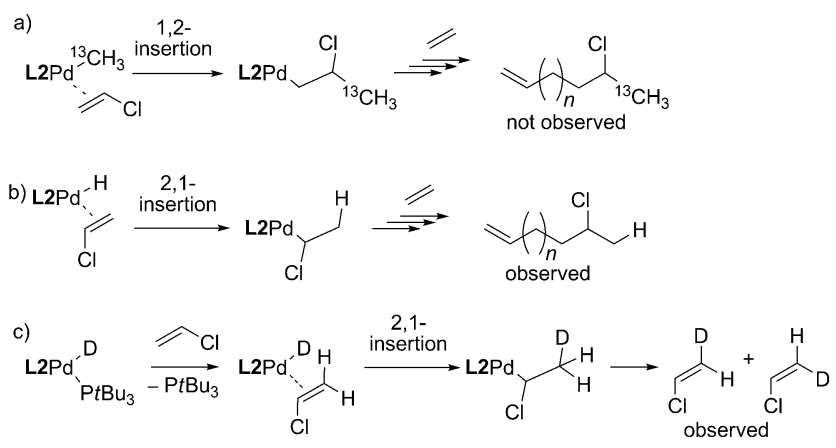

Scheme 3. Experimentally excluded 1,2-insertion of VC in [L2Pd $\left.{ }^{13} \mathrm{CH}_{3}(\mathrm{VC})\right](\mathrm{a})$, and 2,1-insertion of VC into palladium hydride species as a source of ${ }^{12} \mathrm{CH}_{3} \mathrm{CHClCH}_{2}$ - $\mathrm{R}$ units found in ethylene VC copolymers (b) and of 2-deuterated VC in a scrambling experiment (c).

which of these insertion modes is occurring, ${ }^{13} \mathrm{C}$-labeled $\left[\mathbf{L} 2 \mathrm{Pd}^{13} \mathrm{CH}_{3}\right.$ (dmso)] was used as a catalyst precursor. Analysis of the polymers formed (Table 1, entries 12 and 13) indicates that the ${ }^{13} \mathrm{C}$-labeled methyl group is located in $>95 \%$ in the unfunctionalized polymer end group as evidenced by the natural abundance ${ }^{13} \mathrm{CH}_{3} \mathrm{CH}_{2} \mathrm{CH}_{2}$ (S2) end group signal split into a doublet with ${ }^{1} J_{\mathrm{CC}}=34.8 \mathrm{~Hz}$ and the ${ }^{13} \mathrm{C}$-labeled ${ }^{13} \mathrm{CH}_{3} \mathrm{CH}_{2} \mathrm{CH}_{2}$ (S1) signal in comparison to the $\mathrm{CH}_{3} \mathrm{CHClCH}_{2}$ signals (no ${ }^{1} J_{\mathrm{CH}}$, no ${ }^{1} J_{\mathrm{CC}}$, and no signal enhancements as a result of the ${ }^{13} \mathrm{C}$ label were detected; Figure 3 and the Supporting Information). That is, the observed $\mathrm{CH}_{3} \mathrm{CHCl}$ group in the polymer is formed by $2,1-\mathrm{VC}$ insertion into a palladium hydride species [L2PdH(VC)] (Scheme $3 \mathrm{~b}$ ) and not by 1,2-insertion into $\left[\mathbf{L} 2 \mathrm{Pd}^{13} \mathrm{CH}_{3}(\mathrm{VC})\right]$ (Scheme $3 \mathrm{a}$ ).

This result is fully corroborated by a reaction (NMR tube) of palladium deuteride complex $\left[\mathbf{L 2 P d D}\left(\mathrm{P} t \mathrm{Bu}_{3}\right)\right]$ with $\mathrm{VC}$ : this reaction results in scrambling of the deuterium label into the 2-position of VC to yield 2-deuterated VC by 2,1-insertion and $\beta$-hydride elimination, but not into the 1-position to yield 1-deuterated VC (Scheme 3c; for experimental details see the Supporting Information). It is noteworthy, that the use of

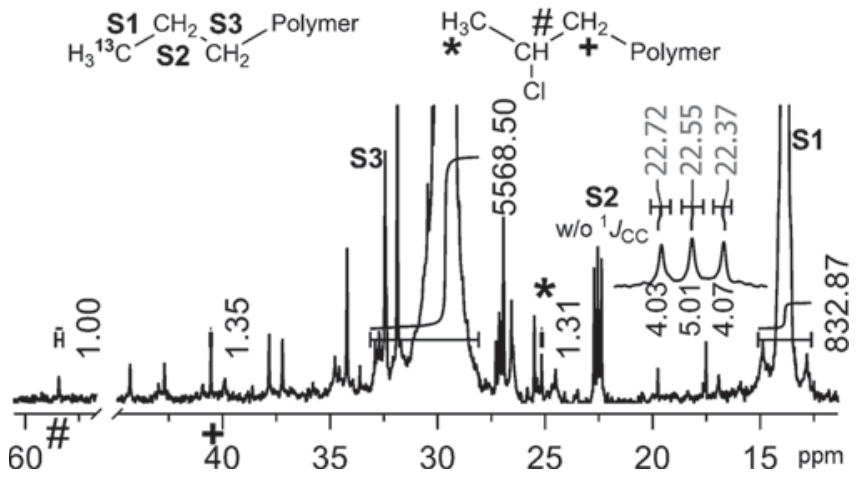

Figure 3. ${ }^{13} \mathrm{C}$ NMR spectrum of ethylene-VC copolymer (entry 13, Table 1) obtained with [ $\mathrm{L} 2 \mathrm{Pd}^{13} \mathrm{CH}_{3}$ (dmso)], indicating ${ }^{1} \mathrm{Cc}_{\text {-coupled S2 }}$ end groups, whereas the $\mathrm{CH}_{3} \mathrm{CHCl}$ end group has natural abundance ${ }^{13} \mathrm{C}$.

$\left[\mathbf{L} 2 \mathrm{PdD}\left(\mathrm{P} t \mathrm{Bu}_{3}\right)\right]$ also enables ethylene-VC copolymerization with incorporation of $\mathrm{CH}_{3} \mathrm{CHClCH}_{2}$ groups reaching $0.4 \mathrm{~mol} \%$ (Table 1, entry 14), although the yield is lower than for reactions using $\left[\mathbf{L} 2 \mathrm{PdCH}_{3}(\mathrm{dmso})\right],\left[\left\{\mathbf{L} 2 \mathrm{PdCH}_{3}\right\}_{2}\right]$, or $\left[\mathbf{L} 4 \mathrm{PdCH}_{3}(\mathrm{dmso})\right]$.

Having established that $\mathrm{VC}$ incorporation into the copolymer proceeds after $\beta$-hydride elimination by insertion into the resultant palladium hydride species, it is evident that the materials obtained are mixtures of ethylene homopolymer chains, initiated by palladium methyl complexes, and of monochlorinated polyethylene (mCPE) chains, initiated by palladium hydride complexes. The ratio of olefinic/ $\mathrm{CH}_{3} \mathrm{CHCl}$ groups enables a rough estimate of the portion of all polymer chains that consist of chlorinated chains. For example, for entry 2 in Table 1 this ratio indicates that approximately every fourth chain is chlorinated and that therefore approximately $30 \%$ of all palladium hydride complexes that initiate chain growth produce VC-containing chains. ${ }^{[19]}$ These results are summarized for all polymerizations in Table 1, column 11.

In conclusion, for the first time an insertion copolymerization of VC with ethylene has yielded chlorine-containing copolymers. NMR analysis of the polymers, labeling, and stoichiometric insertion studies reveal that incorporation of $\mathrm{CHCl}$ units proceeds by 2,1-insertion of $\mathrm{VC}$ into palladium hydride species. After this 2,1-insertion of VC, ethylene insertion resulting in monochlorinated polyethylene is competitive to chain walking (which through the net 1,2-insertion of $\mathrm{VC}$ would result in a detrimental $\beta$-chloride elimination).

Regardless of the limited incorporation of vinyl chloride, this first isolation of chlorine-containing polymers in combination with a mechanistic understanding represents a significant impetus to a long-standing challenge. Future studies will focus on further suppression of chain walking, which results in the problematic net 1,2-insertion of $\mathrm{VC}$, and on facilitating inchain incorporation of $\mathrm{VC}$ into polymers.

Keywords: homogeneous catalysis - insertion · palladium . polymerization · vinyl compounds 
[1] PVC Handbook (Eds.: C. E. Wilkes, C. A. Daniels, J. W. Summers), Carl Hanser Verlag, Munich, 2005.

[2] a) H. W. Boone, P. S. Athey, M. J. Mullins, D. Philipp, R. Muller, W. A. Goddard, J. Am. Chem. Soc. 2002, 124, 8790-8791; b) D. M. Philipp, R. P. Muller, W. A. Goddard, J. Storer, M. McAdon, M. Mullins, J. Am. Chem. Soc. 2002, 124, $10198-$ 10210 ; c) S. R. Foley, R. A. Stockland, H. Shen, Jr., R. F. Jordan, J. Am. Chem. Soc. 2003, 125, 4350-4361; d) S. M. Kilyanek, E. J. Stoebenau III, N. Vinayavekhin, R. F. Jordan, Organometallics 2010, 29, 1750-1760; e) K. Nozaki， B. P. Carrow, J. Am. Chem. Soc. 2012, 134, 8802-8805.

[3] a) L. K. Johnson, S. Mecking, M. Brookhart, J. Am. Chem. Soc. 1996, 118, 267-268; b) S. Mecking, L. K. Johnson, L. Wang, M. Brookhart, J. Am. Chem. Soc. 1998, 120, 888-899.

[4] E. Drent, R. van Dijk, R. van Ginkel, B. van Oort, R. I. Pugh, Chem. Commun. 2002, 744-745.

[5] a) D. Guironnet, P. Roesle, T. Rünzi, I. Göttker-Schnetmann, S Mecking, J. Am. Chem. Soc. 2009, 131, 422-423; b) D. Guironnet, L. Caporaso, B. Neuwald, I. Göttker-Schnetmann, L. Cavallo, S. Mecking, J. Am. Chem. Soc. 2010, 132, 4418-4426.

[6] a) T. Kochi, S. Noda, K. Yoshimura, K. Nozaki, J. Am. Chem. Soc. 2007, 129, 8948-8949; b) K. Nozaki, S. Kusumoto, S. Noda, T. Kochi, L. W. Chung, K. Morokuma, J. Am. Chem. Soc. 2010 132, 16030-16042.

[7] S. Ito, K. Munakata, A. Nakamura, K. Nozaki, J. Am. Chem. Soc. 2009, 131, 14606-14607.

[8] a) W. Weng, Z. Shen, R. F. Jordan, J. Am. Chem. Soc. 2007, 129 , 15450-15451; b) Z. Shen, R. F. Jordan, Macromolecules 2010, 43, 8706-8708.

[9] S. Ito, M. Kanazawa, K. Munakata, J. Kuoda, Y. Okumura, K. Nozaki, J. Am. Chem. Soc. 2011, 133, 1232-1235.

[10] T. Rünzi, D. Fröhlich, S. Mecking, J. Am. Chem. Soc. 2010, 132, $17690-17691$

[11] a) K. M. Skupov, L. Piche, J. P. Claverie, Macromolecules 2008 , 41, 2309-2310; b) T. Friedberger, P. Wucher, S. Mecking, J. Am. Chem. Soc. 2012, 134, 1010-1018.

[12] a) G. J. Domski, J. M. Rose, G. M. Coates, A. D. Bolig, M. Brookhart, Prog. Polym. Sci. 2007, 32, 30-92; b) A. Berkefeld, S. Mecking, Angew. Chem. 2008, 120, 2572-2576; Angew. Chem. Int. Ed. 2008, 47, 2538-2542; c) A. Nakamura, S. Ito, K. Nozaki, Chem. Rev. 2009, 109, 5215-5244; d) E. Y.-X. Chen, Chem. Rev. 2009, 109, 5157-5214.
[13] Note that the reaction of 6-chloro-hex-1-ene with closely related phosphine tolylsulfonato palladium neopentyl yields the respective palladium chloro complex by insertion, chain walking and $\beta$ chloride elimination: J. Vela, G. R. Lief, Z. Shen, R. F. Jordan, Organometallics 2007, 26, 6624-6635.

[14] a) S. Noda, A. Nakamura, T. Kochi, L. W. Chung, K. Morokuma, K. Nozaki, J. Am. Chem. Soc. 2009, 131, 14088-14100; b) T. Rünzi, U. Tritschler, P. Roesle, I. Göttker-Schnetmann, H. M. Möller, L. Caporaso, A. Poater, L. Cavallo, S. Mecking, Organometallics 2012, 31, 8388-8406.

[15] [ $\mathbf{L 2} \mathbf{P d C H}_{3}$ lutidine] and $\left[\mathbf{L} 3 \mathrm{PdCH}_{3}\right.$ lutidine]: a) L. Piche, J.-C. Daigle, G. Rehse, J. P. Claverie, Chem. Eur. J. 2012, 18, 3277 -

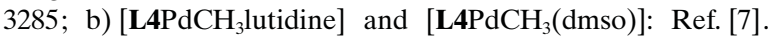
$\left[\mathbf{L} 2 \mathrm{PdCH}_{3}(\mathrm{dmso})\right]$ and $\left[\mathbf{L} 3 \mathrm{PdCH}_{3}(\mathrm{dmso})\right]$ were obtained in analogy to $\left[\mathbf{L} \mathbf{1 P d C H} \mathrm{H}_{3}(\mathrm{dmso})\right]$ : see Ref. [5a]; c) $\left[\left\{\mathbf{L} 2 \mathbf{P d C H}_{3}\right\}_{2}\right]$ has been generated in situ by lutidine abstraction from [L2PdCH $\mathrm{H}_{3}$ lutidine], see Ref. [15a]; we find that $\left[\left\{\mathbf{L} 2 \mathrm{PdCH}_{3}\right\}_{2}\right]$ crystallizes upon heating $\left[\mathbf{L} 2 \mathrm{PdCH}_{3}(\mathrm{dmso})\right]$ in toluene to reflux, see the Supporting Information. CCDC 913301 $\left(\left[\mathbf{L 2} \mathrm{PdCH}_{3} \mathrm{tmeda}_{0.5}\right]\right), \quad 913303 \quad\left(\left[\mathbf{L} 2 \mathrm{PdCH}_{3}(\mathrm{dmso})\right]\right), \quad 913299$ $\left(\left[\left\{\mathbf{L} 2 \mathrm{PdCH}_{3}\right\}_{2}\right]\right), 913300\left(\left[\{\mathbf{L} 3 \mathbf{P d}\}_{2}\right]\right)$, and $913302\left(\left[\mathbf{L} 4 \mathbf{P d C H}_{3}-\right.\right.$ (dmso)]) contain the supplementary crystallographic data for this paper. These data can be obtained free of charge from The Cambridge Crystallographic Data Centre via www.ccdc.cam.ac. uk/data_request/cif.

[16] Isolated $\mathrm{CHCl}$ units incorporated in-chain have characteristic resonances $\left[\delta\left({ }^{13} \mathrm{C}\right)=64.0-64.3 \mathrm{ppm}, \delta\left({ }^{1} \mathrm{H}\right)=3.88-3.89 \mathrm{ppm}\right]$ as determined by: E. Boz, A. J. Nemeth, I. Ghiviriga, K. Jeon, R. G. Alamon, K. B. Wagener, Macromolecules 2007, 40, 6545-6551.

[17] a) 2-Chloroheptane is commercially available; b) 2-Chlorodecane: D. C. Braddock, R. H. Pouwer, J. W. Burton, P. Broadwith, J. Org. Chem. 2009, 74, 6042-6049; c) 12-Chlorotridecan-1-ol: M. Yasuda, K. Shimizu, S. Yamasaki, A. Baba, Org. Biomol. Chem. 2008, 6, 2790-2795.

[18] The possibility of a Markownikow addition of $\mathrm{HCl}$ to $\alpha$-olefinic polymer chains was excluded on the basis of control experiments.

[19] This estimate accounts for formation of one ethylene homopolymer chain by palladium methyl complexes $\left[\mathbf{L} 2 \mathrm{PdCH}_{3}(\mathrm{dmso})\right]$, $\left[\left\{\mathbf{L} 2 \mathrm{PdCH}_{3}\right\}_{2}\right]$, and $\left[\mathbf{L} 4 \mathrm{PdCH}_{3}(\mathrm{dmso})\right]$ prior to formation of mCPE chains by palladium hydrides. Note that when starting from $\left[\mathbf{L 2} \mathrm{PdH}\left(\mathrm{P} t \mathrm{Bu}_{3}\right)\right]$ (entry 14 , Table 1 ) approximately $36 \%$ of all palladium hydride species form mCPE chains. 